\title{
Development of Sitting Type Coconut Palm Climbing Device
}

\author{
V.V. Agravat ${ }^{1 *}$, P. Mohnot ${ }^{2}$, R.H. Desai ${ }^{1}$, P.R. Balas ${ }^{1}$ and R. Yadav $^{2}$ \\ ${ }^{1}$ Department of Farm Machinery and Power Engg., ${ }^{2}$ Department of Farm Engg., Junagadh \\ Agricultural University, Junagadh, India \\ *Corresponding author
}

\section{A B S T R A C T}

\section{Keywords \\ Coconut, Coconut palm climbing device, Sitting type climbing device \\ Article Info \\ Accepted: \\ 24 August 2018 \\ Available Online: \\ 10 September 2018}

Coconut (Cocos Nucifera L.) belongs to the family of palms. The sitting type coconut palm climbing device was fabricated at Department of Farm Machinery and Power Engineering, College of Agricultural Engineering and Technology, Junagadh Agricultural University, Junagadh. The sitting type coconut palm climbing device consists two different units namely upper unit and lower unit. The main components of the device were approach section, junction, seat support pipe, base pipe, seat, telescopic pipe, metal rope, and gripping face plate. One single operator can easily climb the coconut palm with complete safety. Weight of the device was $4.5 \mathrm{~kg}$. The device could sustain the external load up to $160 \mathrm{~kg}$.

\section{Introduction}

India ranks second worldwide in horticulture produces. The scenario of horticultural crops in India has become very encouraging. The percentage share of horticulture output in agriculture has become more than $30 \%$. Over the last decade, the area under horticulture grew by about $2.7 \%$ per annum and annual production increased by $7.0 \%$. During 201314 , the production of horticultural crops was about 283.5 million tonnes from an area of 24.2 million hectares (NHB, 2015).

Coconut (Cocos nucifera L.) belongs to the family of palms, Palm included under the lower group of flowering plants known as the monocotyledons. Coconut is mainly grown in tropical countries. Indonesia and Philippines are the first and the second largest coconut producing countries in the world. India is the third largest coconut producing country having an area of about 1.97 million ha with a production of 15.7 million tons (NHB, 2015). The production of coconut is mostly in the southern part of India. Major areas of coconut cultivation in India are the states of Kerala, Tamil Nadu, Karnataka, Andhra Pradesh, Odisha, West Bengal, Pondicherry, Maharashtra and the islands of Lakshadweep and Andaman \& Nicobar. Four southern states put together account for almost $91 \%$ of the 
total production of coconut in the country: Kerala (21.46\%), Tamil Nadu (30.31\%), Karnataka (32.85\%) and Andhra Pradesh (6.60\%). Other states like Gujarat, Maharashtra, Odisha, Goa, West Bengal and those in the northeast like Tripura and Assam account for the remaining 8.77 per cent.

Gujarat ranks sixth in area and seventh in production of coconut in India. Gujarat has coastline of $1600 \mathrm{~km}$ which is suitable for coconut plantation. Total coconut production of the state is 2.03 million tons under area of 31,630 ha (NHB, 2015).

There are several industries, which depend on coconut as raw material, for its processing and manufacturing of various value-added products. The inflorescence sap of coconut palms used to produce desiccated coconut and its powder, packed coconut milk, coconut cream, coconut milk powder, tender coconut water, vinegar, nata-de-coco, etc. are few of them.

The trained climber may charge high wages because of their scarcity. Due to the risk involved nowadays very few people are coming forward to climb on coconut palms. In recent years, the number of coconut palm climbers has declined sharply, as those men who do this rigorous job of climbing 30 to 80 feet high above the ground, bare handed or with the help of a rope, have broken away from their traditional role to take-up better paid jobs moreover as the educational background of Indian youth is increasing most of the people may hesitate to come in this type of profession (Edacheri et al., 2011).

Mohanraj et al., (2014) reported that in spite of repeating six to twelve times or even more in a year the climbing for harvesting is tedious and difficult. A few years back local climbers were available for harvesting and other activities at the crown of the coconut palms.
Presently, the population of these climbers is decreasing and not available even at higher wages. Visualizing the above problem, scientist/ researcher/ innovators have worked to provide a solution for this acute problem. Various types of climbing devices such as tractor operated, self-propelled, robotic devices and manual methods were developed but most of them are at laboratory level, only a few were adopted by the farmers.

Jaikumaran et al., (2016) developed a sitting type coconut palm climbing device (Kera Suraksha Coconut Climber). It is made of mild steel and weighing $9.35 \mathrm{~kg}$. $6 \mathrm{~mm}$ metal rope is used as gripping aid. Its field performance and ergonomic evaluation were conducted. The total time taken by the operator to climb a $12 \mathrm{~m}$ height palm using the developed climbing device was 3.16 minutes. The angle of inclination of the upper metal rope, lower metal rope and seat with horizontal was found to be within safe value of $40^{\circ}$. The bearing capacity of the materials of climbing device as a whole was found to be $165 \mathrm{~kg}$ and did not shown any failure.

Corlett and Clarke (1976) stated that ergonomics is the tailoring of products, so that the human user involved is as comfortable as possible with minimized stress and fatigue. Health, safety and productivity benefits often result from this worker friendly approach. Most designer of agricultural equipment concentrated to improve efficiency and durability, but none seem to give importance to the operator comfort. Generally, the operator is also a part of the machine system. The combination of an operator and a farm implement is not typically an issue for shortterm users, but becomes more critical for long term users. Long term users generally report a great deal of discomfort or pain.

There are some existing devices being used for coconut palm climbing are as follows: 
Standing type coconut palm climbing device: It is made up of mild steel, steel rope and rubber pad. In this device, the top and the bottom parts are looped with the steel rope. The user has to be in standing posture on the device and lift it manually using steel rope. As the height of the tree increases the risk of using this device is also high (Fig. 1).

Sitting type coconut palm climbing device: In sitting type devices, generally there is provision of upper section and lower section. The upper frame can be lifted by hands and the lower frame has to be lifted by legs. Due to sitting facility, it does not create much body ache. Operator can work more safely using this model as compare to standing type model (Fig. 2).

Tractor mounted hydraulic elevator for coconut harvesting: It is also available in market. From safety point of view it is quite good but it is costly among all the equipment. Tractor should be near to the palm at the time of harvesting but sometimes tractor cannot reach near to the palm due to narrow spacing (Fig. 3).

Motorised coconut palm climbing device was also developed but it is not suitable for practical usage due to its heavy weight. It consumes fuel and much difficult to attach and detach with the trunk. Monkeys are trained for coconut harvesting in Monkey Training School at Surath Thani, Thailand (Ratnambal, 1997). But monkey cannot judge the maturity of nuts and this method actually damages the nuts because monkey throws it down after plucking.

Coconuts are being harvested by men simply climbing a palm without any protection. Although these people are quite good at what they do, there is still some chance of injury to these climbers. There is also a chance to fall down from the palm. Especially in Gujarat coconut growing farmers are completely dependent on the labourers for picking the nuts. Labourers have to climb on the palm by proper gripping on the trunk because of the structure of coconut palm it is very rough to harvest coconut. An equipment which helps to climb the coconut palm would be beneficial. These farmers need a coconut climbing device that is simple in design, affordable, feasible to attach with the palm and easy to operate. This device is not consuming power hence no requirement of fuel or electricity. It makes farmer independent. Any farmer or householder can easily harvest the nuts using device.

Anon. (2013a) suggested that the posture of an operator in controlling a machine or carrying out an activity is largely determined by job requirements. There are four widely used postures standing, bending, squatting and sitting. The sitting posture is superior to all postures in several ways. There is a reduction of fatigue and operator can perform light work with arms and heavy work with the legs for a much longer time than other postures. There is increased stability in seated position. Another advantage of seated position is that it enables more effective operation of control pedal in various machines.

Anon. (2013b) mentioned that standing type coconut palm climbing device is applicable for trunk diameter 15 to $32 \mathrm{~cm}$. Weight of the device is $7.9 \mathrm{~kg}$. Jaikumaran et al., (2016) developed a sitting type coconut palm climbing device (Kera Suraksha Coconut Climber). It is made of mild steel and weighing $9.35 \mathrm{~kg}$. $6 \mathrm{~mm}$ metal rope is used as gripping aid. Its field performance and ergonomic evaluation were conducted. The total time taken by the operator to climb a 12 $\mathrm{m}$ height palm using the developed climbing device was 3.16 minutes. The angle of inclination of the upper metal rope, lower metal rope and seat with horizontal was found 
to be within safe value of $40^{\circ}$. The bearing capacity of the materials of climbing device as a whole was found to be $165 \mathrm{~kg}$ and did not shown any failure. Sridhar et al., (2017) developed sitting type coconut palm climbing device and had used rubber pads to prevent the slippage.

\section{Materials and Methods}

The methodology was used for the development of sitting type coconut palm climbing device as follow.

\section{General considerations}

As a part of general consideration following physical parameters of coconut palm were taken into account for the development of sitting type coconut palm climbing device.

\section{Height of coconut palm}

Coconut palm having three different heights (7, 9 and 11 meter namely $\mathrm{H}_{1}, \mathrm{H}_{2}$ and $\mathrm{H}_{3}$ respectively) was selected for this study. Height of the palm was measured with the help of bamboo pole that has markings at every a meter. Total 54 coconut palms were selected for this experiment.

\section{Girth of coconut palm}

The girth of total 54 palms was measured at three levels of height i.e. at one meter height above ground level, at middle portion and at one meter below the junction of trunk and crown. Because at the time of climbing the coconut palm, operator attach the device with trunk. That time he normally fixes it about one meter above from ground. Generally, the girth of coconut tree decreases with increase in height, so developed device should be fit throughout the girth. Hence middle part girth and girth from one meter below from crown junction was also measured.

\section{Development of various components of sitting type coconut palm climbing device}

Sitting type coconut palm climbing device consists two units called upper unit and lower unit. Its components described as following.

\section{Approach section}

It is one of the important part of sitting type coconut climbing device. It was fabricated from the GI hollow square pipe having square cross section of $16 \mathrm{~mm}$ with $2 \mathrm{~mm}$ thickness and $280 \mathrm{~mm}$ length. There were seven holes of $8 \mathrm{~mm}$ diameter drilled at the distance of 25 $\mathrm{mm}$ on it (as shown in Fig. 4) to facilitate sliding of telescopic pipe over it. One end of the pipe was meant to be connected with the junction with the help of M6×50 mm full threaded bolt. Four approach sections were fabricated among which two pipes namely, upper left and upper right for upper unit whereas other two pipes namely lower left and lower right for lower unit. Construction details of approach section are depicted in Figure 5. All four approach section has same dimensions.

\section{Junction (for upper unit and lower unit)}

Total two junctions were fabricated for the device namely upper junction (at upper unit) and lower junction (at lower unit).

Upper junction helps to joint approach section with seat support pipe for upper unit while lower junction helps to joint approach section with feet rest. Both junctions have same dimensions. Firstly, GI hollow rectangular pipe having internal dimension of $22 \times 67 \mathrm{~mm}$ and thickness of $1.5 \mathrm{~mm}$ and $50 \mathrm{~mm}$ length were cut length wise and welded with its short side to a GI square pipe having of $38 \mathrm{~mm}$ internal dimension with $1.5 \mathrm{~mm}$ thickness and $50 \mathrm{~mm}$ length which shown in Figure 6. Holes of $8 \mathrm{~mm}$ diameter were drilled at the center of the pipes as shown in Figure 7. 


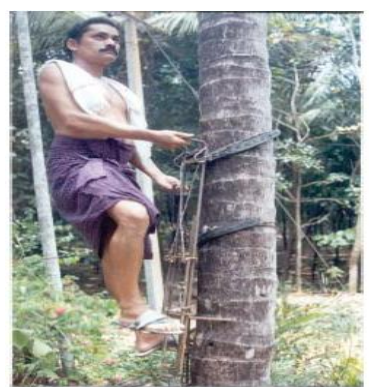

Fig.1 Standing type coconut palm climbing device

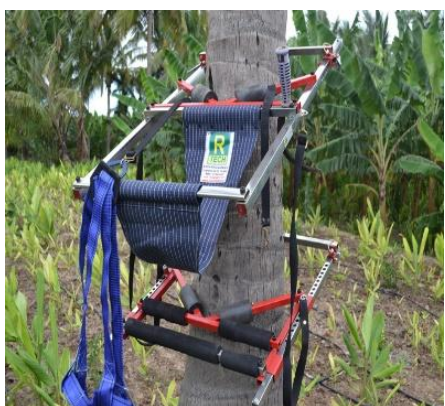

Fig.2 Sitting type coconut palm climbing device

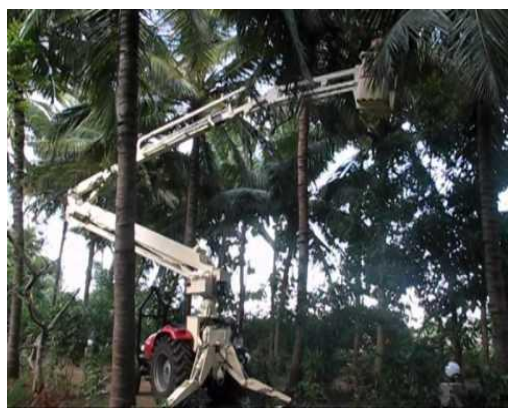

Fig.3 Tractor mounted hydraulic elevator

Fig.4 Construction details of approach section

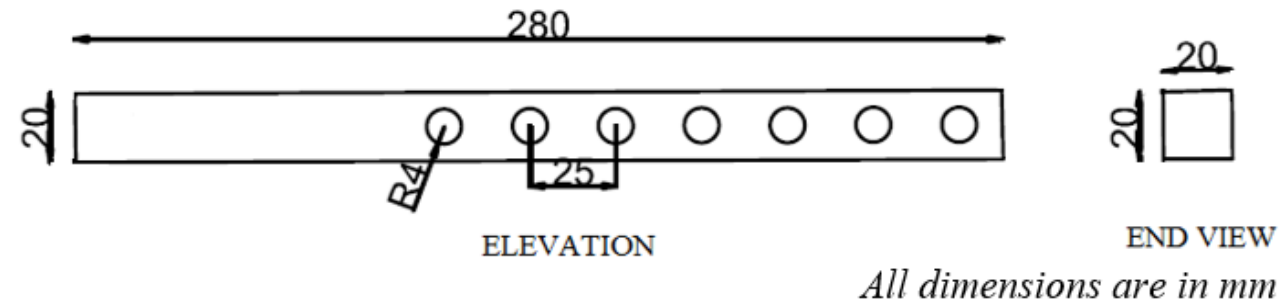

Fig.5 Approach section

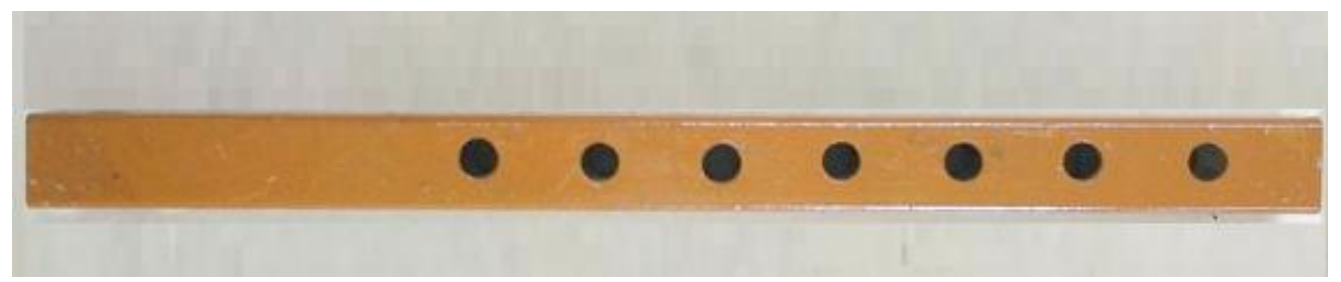

Fig.6 Construction details of junction
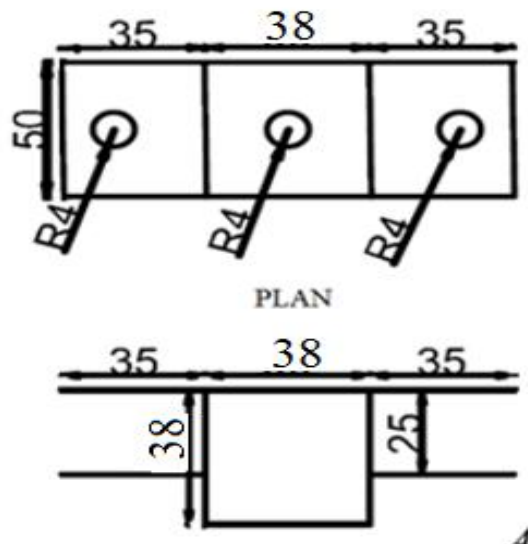

ELEVATION 
Fig.7 Junction

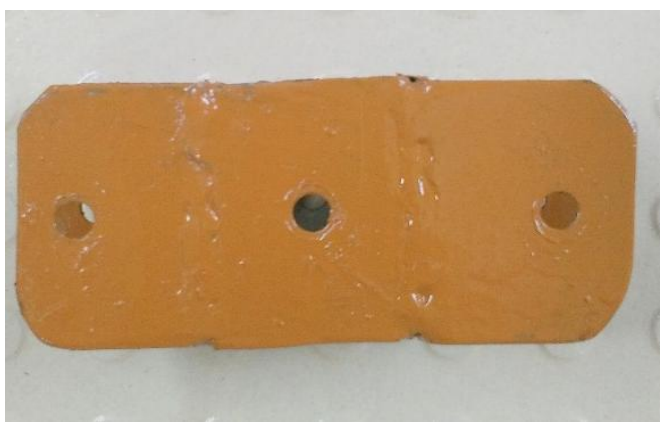

Fig.9 Construction details of gripping face plate

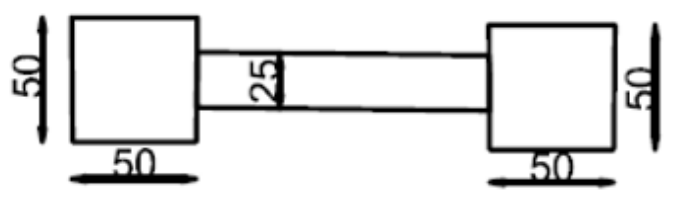

PLAN

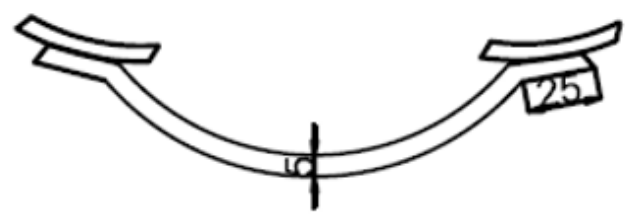

\section{ELEVATION All dimensions are in $\mathrm{mm}$}

Fig.10 Gripping face plate with base pipe

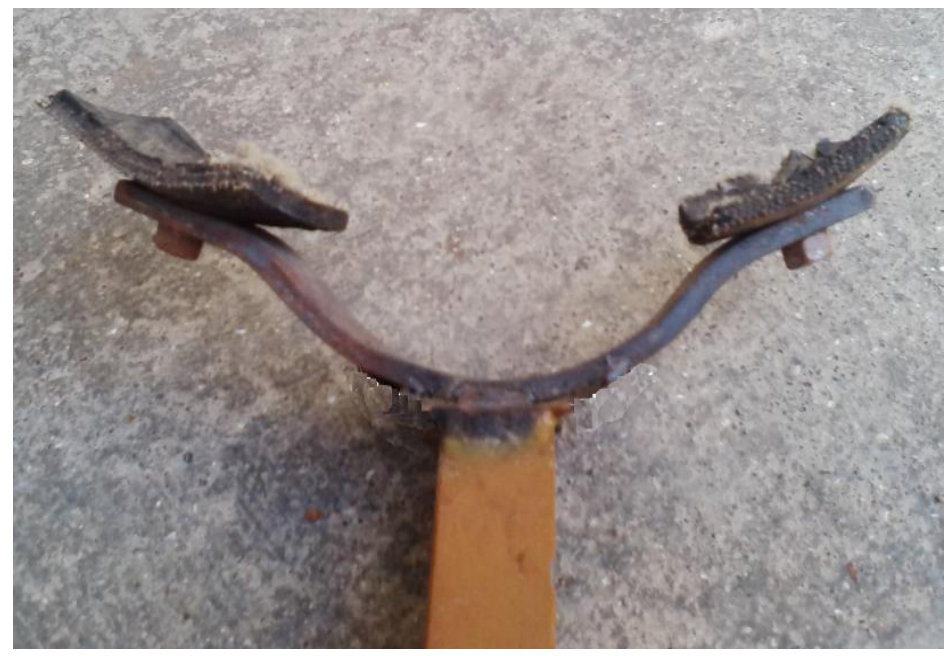


Fig.11 Constructional details of telescopic pipe
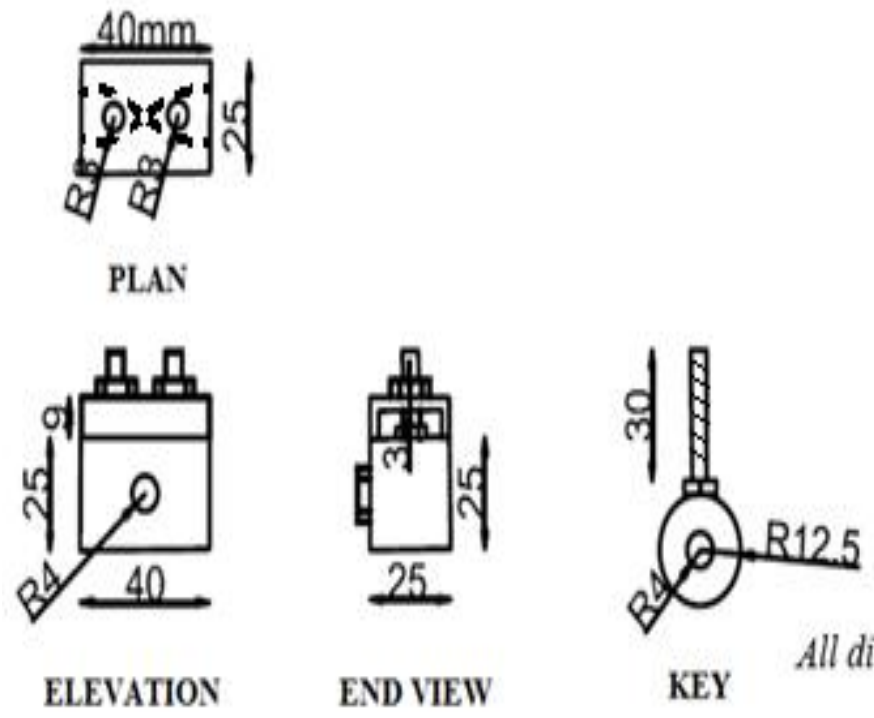
END VIEIV

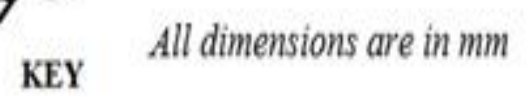

Fig.12 Telescopic pipe

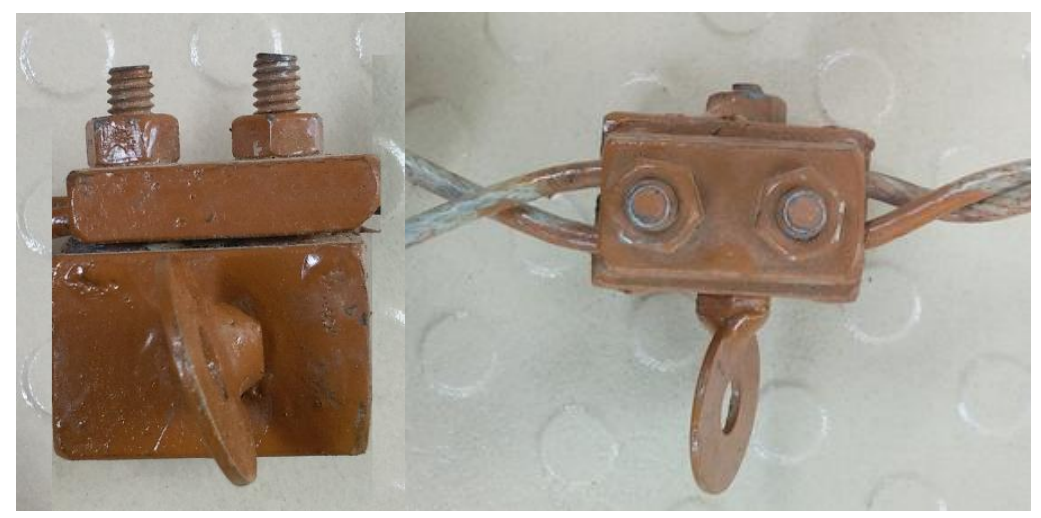

Fig.13 Top and bottom view of seat
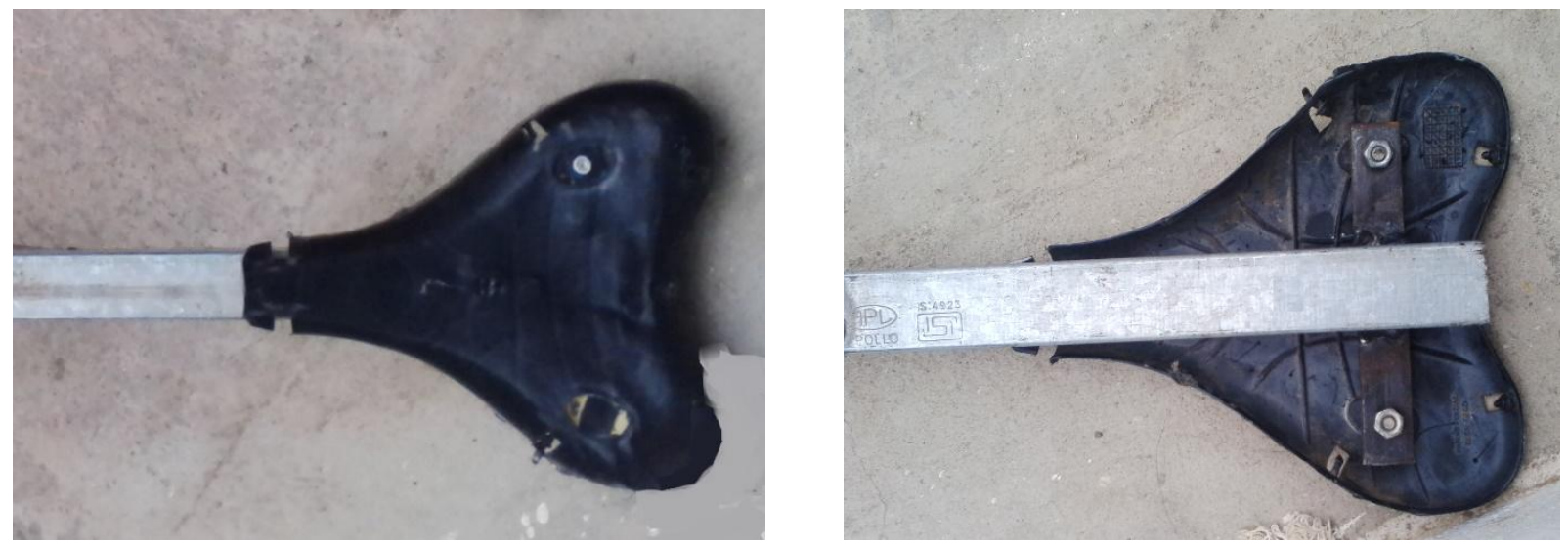
Fig.14 Constructional details of feet rest

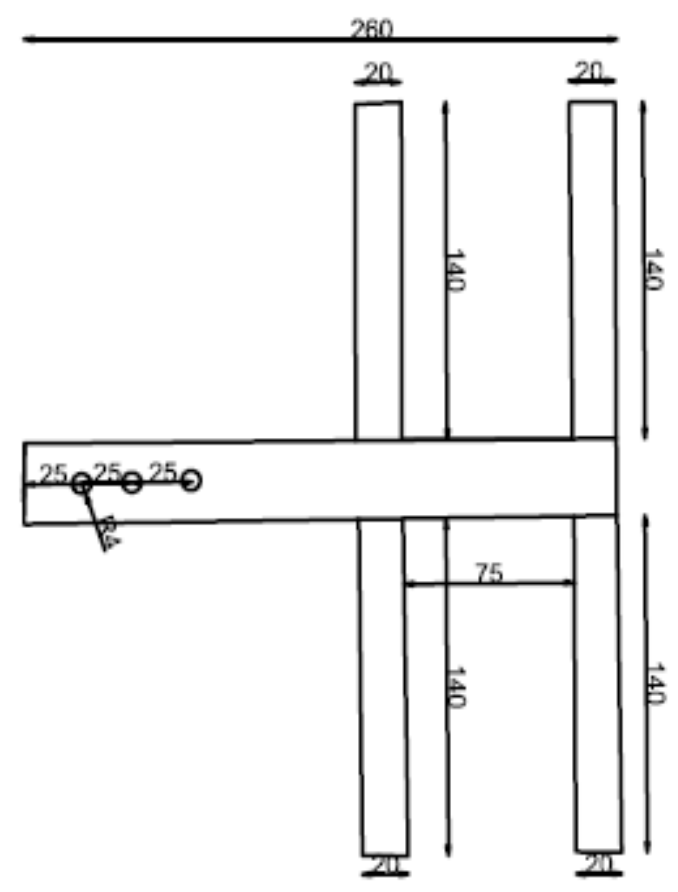

PLAN

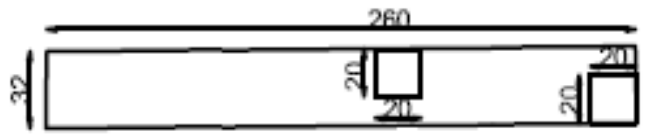

ELEVATION

Fig.15 Feet rest

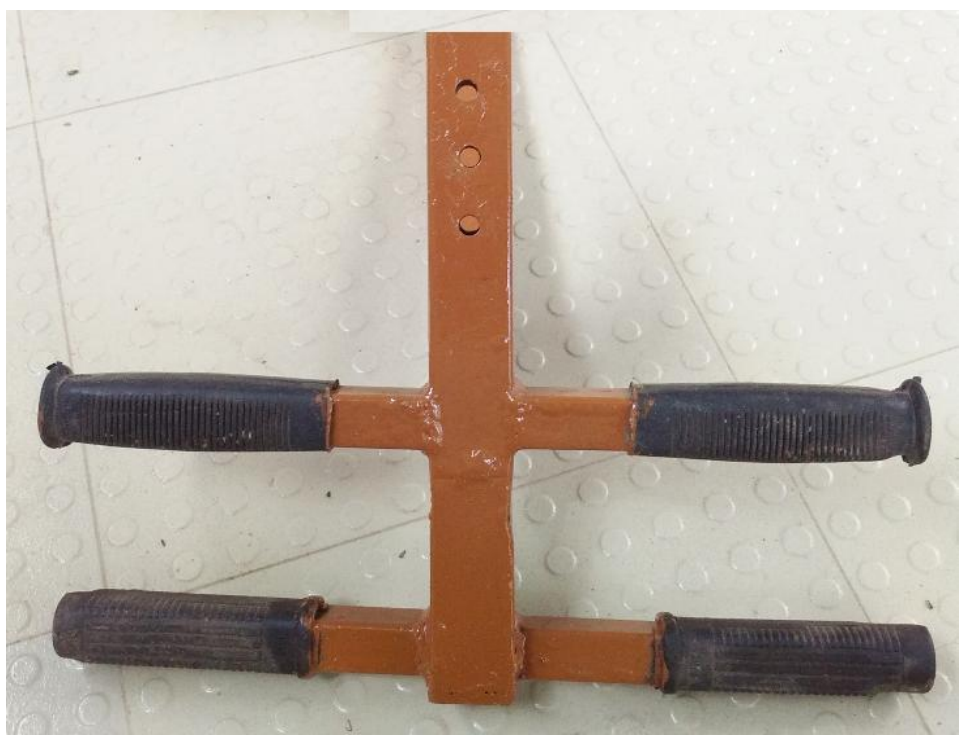


Fig.16 Detailed assembly of sitting type coconut plam climbing device

\section{UPPER UNIT}
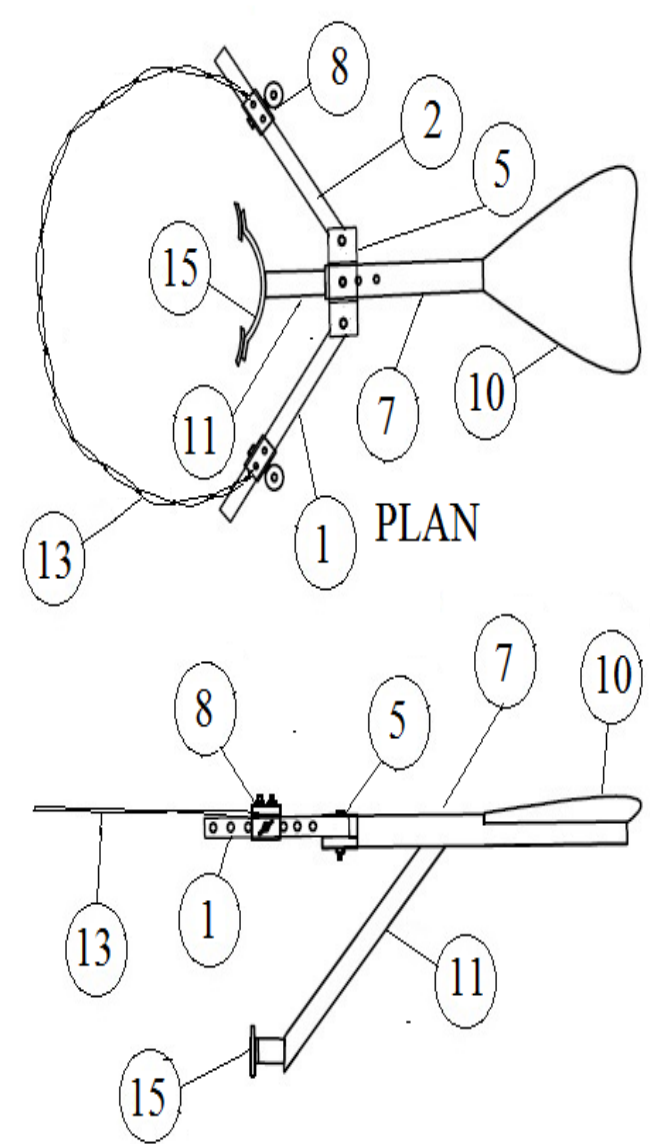

ELEVATION

\section{LOWER UNIT}
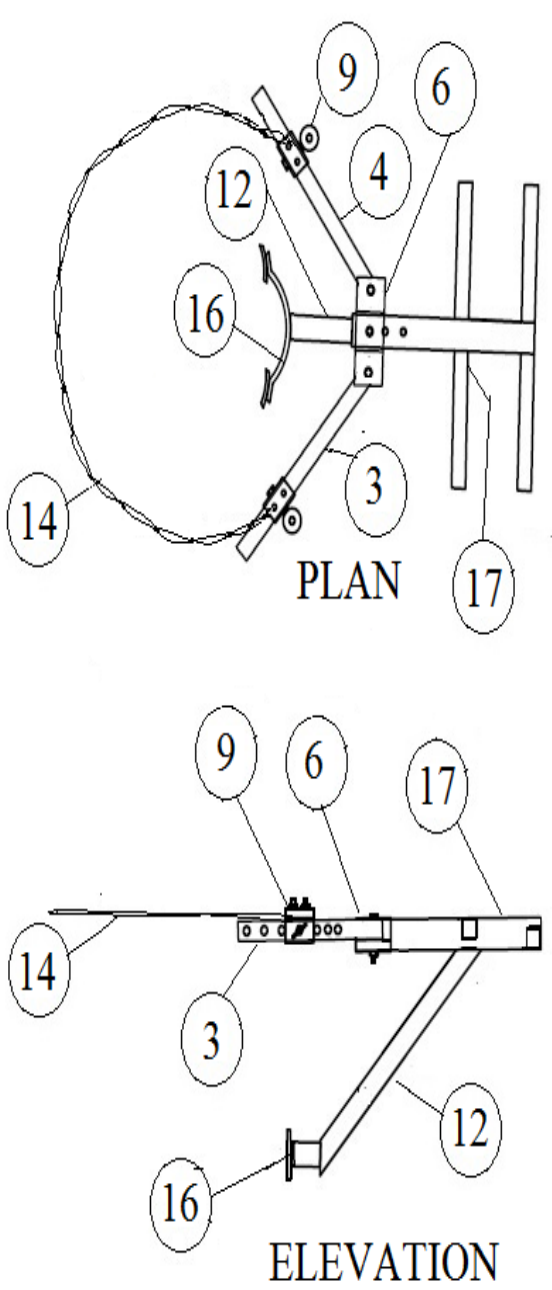

\begin{tabular}{|c|c|c|c|}
\hline 17 & FEET REST & $\begin{array}{l}16 \mathrm{~mm} \text { square GI pipe with } 2 \mathrm{~mm} \text { thickness, } \\
29 \mathrm{~mm} \text { square GI pipe with } 1.5 \mathrm{~mm} \text { thickness }\end{array}$ & 1 No. \\
\hline 16 & $\begin{array}{l}\text { LOWER GRIPPING FACE } \\
\text { PLATE }\end{array}$ & MS flat $25 \times 6 \mathrm{~mm}$ & $210 \mathrm{~mm}$ \\
\hline 15 & $\begin{array}{l}\text { UPPER GRIPPING FACE } \\
\text { PLATE }\end{array}$ & MS flat $25 \times 6 \mathrm{~mm}$ & $210 \mathrm{~mm}$ \\
\hline 14 & LOWER METAL ROPE & $6 \mathrm{~mm}$ plastic coated galvanized & $600 \mathrm{~mm}$ \\
\hline 13 & UPPER METAL ROPE & $6 \mathrm{~mm}$ plastic coated galvanized & $600 \mathrm{~mm}$ \\
\hline 12 & LOWER BASE PIPE & $22 \mathrm{~mm}$ square $\mathrm{GI}$ pipe with $1.5 \mathrm{~mm}$ thickness & $330 \mathrm{~mm}$ \\
\hline 11 & UPPER BASE PIPE & $22 \mathrm{~mm}$ square $\mathrm{GI}$ pipe with $1.5 \mathrm{~mm}$ thickness & $330 \mathrm{~mm}$ \\
\hline 10 & SEAT & PVC, Available bicycle seat & 1 No. \\
\hline 9 & LOWER TELESCOPIC PIPE & $\begin{array}{l}22 \mathrm{~mm} \text { square GI pipe with } 1.5 \mathrm{~mm} \text { thickness, } \\
\text { MS channel } 25 \times 9 \times 9 \times 3 \mathrm{~mm}\end{array}$ & 2 Nos. \\
\hline 8 & UPPER TELESCOPIC PIPE & $\begin{array}{l}22 \mathrm{~mm} \text { square } \mathrm{Gl} \text { pipe with } 1.5 \mathrm{~mm} \text { thickness, } \\
\text { MS channel } 25 \times 9 \times 9 \times 3 \mathrm{~mm}\end{array}$ & 2 Nos. \\
\hline 7 & SEAT SUPPORT PIPE & $29 \mathrm{~mm}$ square $\mathrm{GI}$ pipe with $1.5 \mathrm{~mm}$ thickness & $435 \mathrm{~mm}$ \\
\hline 6 & LOWER JUNCTION & $\begin{array}{l}35 \mathrm{~mm} \text { square } \mathrm{Gl} \text { pipe with } 1.5 \mathrm{~mm} \text { thickness, } \\
67 \times 22 \mathrm{Gl} \text { pipe with } 1.5 \mathrm{~mm} \text { thickness }\end{array}$ & 1 No. \\
\hline 5 & UPPER JUNCTION & $\begin{array}{l}35 \mathrm{~mm} \text { square } \mathrm{Gl} \text { pipe with } 1.5 \mathrm{~mm} \text { thickness, } \\
67 \times 22 \mathrm{Gl} \text { pipe with } 1.5 \mathrm{~mm} \text { thickness }\end{array}$ & 1 No. \\
\hline 4 & $\begin{array}{l}\text { LOWER RIGHT APPROACH } \\
\text { SECTION }\end{array}$ & $16 \mathrm{~mm}$ square Gl pipe with $2 \mathrm{~mm}$ thickness & $280 \mathrm{~mm}$ \\
\hline 3 & $\begin{array}{l}\text { LOWER LEFT APPROACH } \\
\text { SECTION }\end{array}$ & $16 \mathrm{~mm}$ square GI pipe with $2 \mathrm{~mm}$ thickness & $280 \mathrm{~mm}$ \\
\hline 2 & $\begin{array}{l}\text { UPPER RIGHT APPROACH } \\
\text { SECTION }\end{array}$ & $16 \mathrm{~mm}$ square GI pipe with $2 \mathrm{~mm}$ thickness & $280 \mathrm{~mm}$ \\
\hline 1 & $\begin{array}{l}\text { UPPER LEFT APPROACH } \\
\text { SECTION }\end{array}$ & $16 \mathrm{~mm}$ square GI pipe with $2 \mathrm{~mm}$ thickness & $280 \mathrm{~mm}$ \\
\hline SN & DESCRIPTION & MATERIAL & QTY. \\
\hline \multicolumn{4}{|c|}{ Sitting Type Coconut Palm Climbing Device } \\
\hline
\end{tabular}


Fig.17 Screenshots of SolidWorks software to determine the capacity of the device

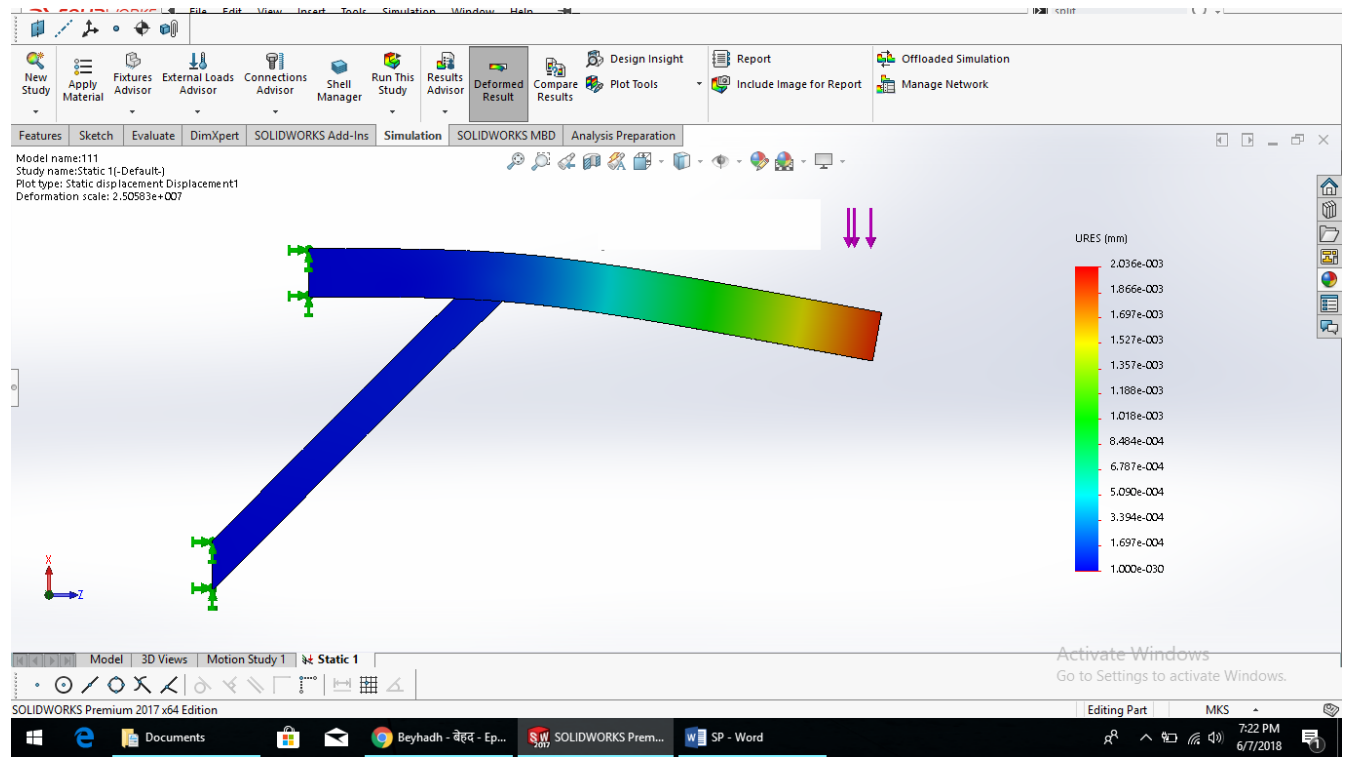

Fig.18 Operator working with developed device

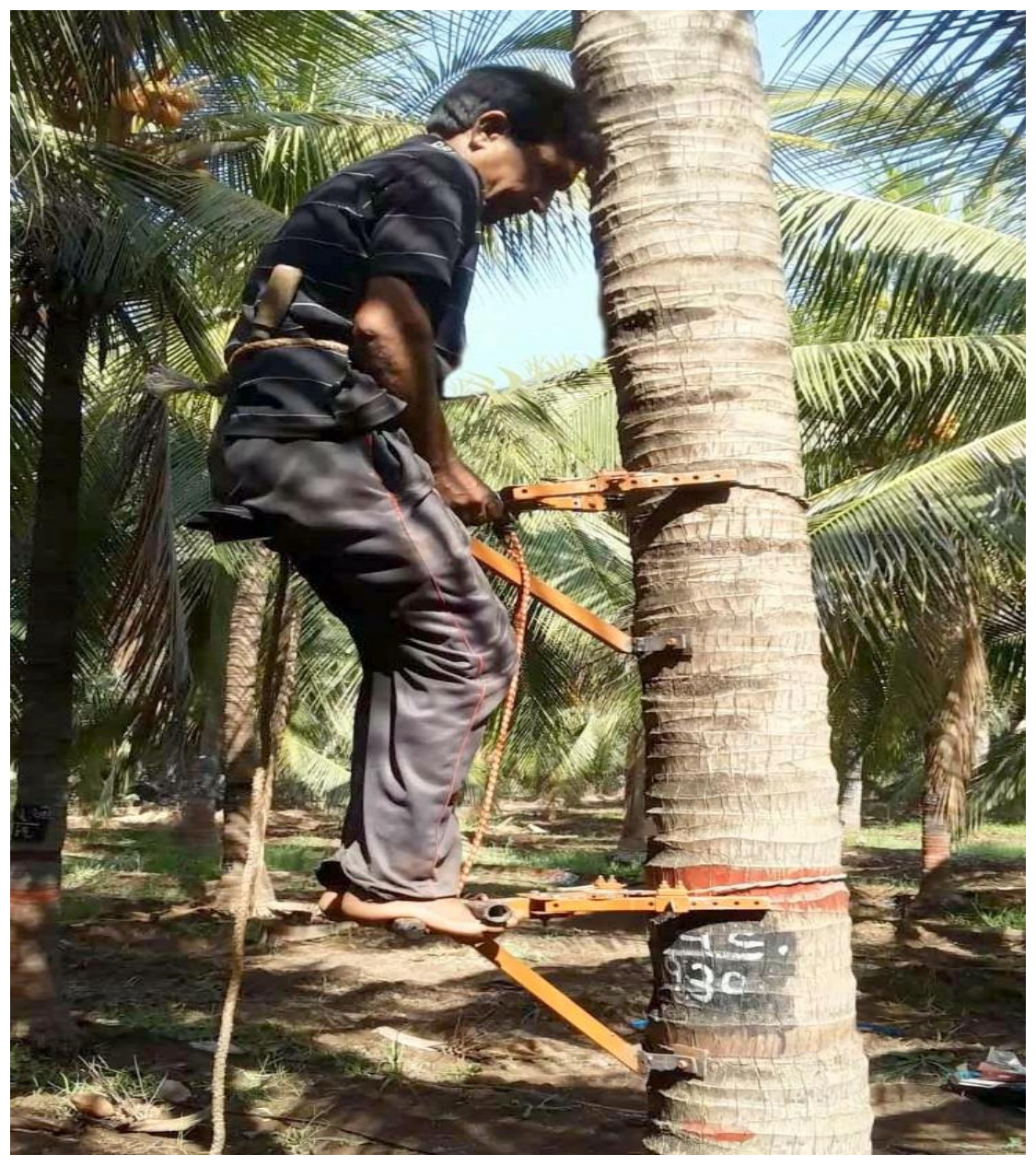


The M6×50 mm full threaded bolts were meant to attach approach section with the junction.

\section{Gripping face plate with base pipe (for} upper unit and lower unit)

As its name suggests gipping face plate provides grip with trunk during operation. Construction details of gripping face plate are shown in Figure 9. A $25 \times 6 \mathrm{~mm}$ MS flat having length of $210 \mathrm{~mm}$ was used. Then two holes with $8 \mathrm{~mm}$ diameter were drilled at both the end of the MS flat at the distance of 20 $\mathrm{mm}$ from outer end. As shown in Figure 10. It was bent at the radius of $25 \mathrm{~mm}$. Then two M6×50 mm full threaded bolts were taken and their heads were grinded up to $2 \mathrm{~mm}$ with the help of bench grinder. So that head of the bolt does not harm the trunk of the coconut palm. At the holes, piece of tires having size of $50 \times 50 \mathrm{~mm}$ were fitted with bolt. Finally, gripping face plate was welded with the base pipe $(22 \mathrm{~mm}$ square GI pipe with $1.5 \mathrm{~mm}$ thickness having length of $330 \mathrm{~mm}$ ) in such a way that it makes angle of $135^{\circ}$. Total two gripping face plates are used in the device namely upper gripping face plate for upper unit and lower gripping face plate for lower unit.

\section{Telescopic pipe}

Telescopic pipe is used to provide adjustment to the device with different girths of coconut palm and also it holds the metal rope having thickness of $6 \mathrm{~mm}$. Earlier the metal rope was twisted. Telescopic pipe was fabricated from a $22 \times 22 \mathrm{~mm}$ GI square pipe having $1.5 \mathrm{~mm}$ thickness and length of $40 \mathrm{~mm}$. Two M6×20 $\mathrm{mm}$ full threaded bolts were welded from its head on GI pipe by keeping distance between them as $20 \mathrm{~mm}$. Then metal rope was fixed between these two bolts. Then two holes of 6 $\mathrm{mm}$ diameter were drilled on $25 \times 9 \times 9 \mathrm{~mm}$ MS channel having $3 \mathrm{~mm}$ thickness length of 40 $\mathrm{mm}$. After that it was fixed with the help of two $6 \mathrm{~mm}$ hexagonal nuts on these bolts through the holes. A key was fabricated to control sliding movement of telescopic pipe. It was made by a washer welded at the head of M6×50 mm full threaded bolt slides over the approach section. Total four telescopic pipes were fabricated with same dimensions in which two (upper telescopic pipe) for upper unit and two (lower telescopic pipe) for lower unit. Constructional details of telescopic pipe are shown in Figure 12.

\section{Seat}

To provide sitting facility to the operator available heart shaped bicycle seat was used. Figure 13 shows the top and bottom view of the seat. The seat was fixed on seat support pipe $(29 \times 29 \mathrm{~mm}$ GI square pipe having thickness of $1.5 \mathrm{~mm}$ with the length of 435 $\mathrm{mm})$.

First of all a $20 \times 6 \mathrm{~mm}$ MS flat having length of $140 \mathrm{~mm}$ was selected to provide base for seat. Holes of $8 \mathrm{~mm}$ diameter were drilled at both ends of MS flat with the distance of 20 $\mathrm{mm}$ from near end. On it seat was fitted. Overall seat size is $210 \times 180 \mathrm{~mm}$.

\section{Feet rest}

Feet rest is the component of the lower unit of the device. Its constructional details are shown in Figure 14. A $29 \times 29 \mathrm{~mm}$ GI square pipe with $1.5 \mathrm{~mm}$ thickness and the length of $260 \mathrm{~mm}$ was taken. On it at one side three holes of $8 \mathrm{~mm}$ diameter were drilled at the spacing of $25 \mathrm{~mm}$ from each other that provide facility to slide inside the junction.

Then total four GI square pipes $(16 \times 16 \mathrm{~mm})$ with $2 \mathrm{~mm}$ thickness and the length of 140 $\mathrm{mm}$ were welded with the $29 \times 29 \mathrm{~mm}$ pipe in such a way that toe lift the front pipe and heel push the rear pipe. To provide comfort to the 
operator rubber grips are provided which is shown in Figure 15.

\section{Capacity of the device}

Maximum allowable stress of the device was found using SolidWorks software. It was found as $160 \mathrm{~kg}$. Deformation found in GI square pipes was $2 \mathrm{~mm}$ when $160 \mathrm{~kg}$ load was applied at the seat part. Screen shots taken at the time of using software is shown in Figure 17.

\section{References}

Anonymous. (2013a). Handbook of Agricultural Engineering. ICAR Publ. New Delhi.

Anonymous. (2013b). National Innovation Foundation, India. Tree climber. http://nif.org.in/innovation/tree-climber/ 495. Accessed on $24^{\text {th }}$ Sept. 2017.

Anonymous. (2017a). Agriculture in India. Wikipedia: the free encyclopedia. https://en.wikipedia.org/wiki/Agricultur e_in_India. Accessed on $14^{\text {th }}$ Sept. 2017.

Corlett, H. D. and Clarke, R. P. (1976). A technique for accessing postural discomfort. Ergonomics. 19(2): 175182.

Edacheri, D., Kumar, S. and Unakal, P. (2011). Design of a coconut palm climbing device. J. SAS Tech. 10(2): 87-94.

Jaikumaran, U., Joseph, S., Preman, P., Unnikrishnan, C., Jitha, K. and Joseph, C. (2016). Design and development of sitting type coconut palm climbing device- Kera Suraksha Coconut Climber. Journal of Tropical Agriculture. 54(1): 136-143.

Mohanraj, A. P., Raghulkrishna, S., Kannan, S., Rajkumar, M. and Elango, A. (2014). Design and analysis of a coconut harvesting maneuver. International Journal of Scientific \& Engineering Research. 5(5): 508-512.

NHB. (2015). Indian Horticulture Database 2014 [On-line]. National Horticulture Board (NHB). Available on http://nhb.gov.in/areapro/NHB_Databas e_2015. pdf. Accessed on 14th September 2017.

Sridhar, N., Surendrakumar A. and Selvakumar, C. (2017). Performance evaluation and modification of coconut tree climber. Int. J. Curr. Microbiol. App. Sci. 6(12): 1195-1201.

\section{How to cite this article:}

Agravat, V.V., P. Mohnot, R.H. Desai, P.R. Balas and Yadav, R. 2018. Development of Sitting Type Coconut Palm Climbing Device. Int.J.Curr.Microbiol.App.Sci. 7(09): 3591-3602. doi: https://doi.org/10.20546/ijcmas.2018.709.445 